\title{
Mixed reaction to Mandela's appointments
}

Cape Town. Pre-election hopes that science would be given its own government department in South Africa were partly fulfilled last week when Nelson Mandela, the country's first democratically elected president, announced the creation of a Ministry for Arts, Culture, Science and Technology in his new cabinet.

But enthusiasm for this initiative has been tempered by the appointment of Ben Ngubane, a political supporter of Chief Mangosuthu Buthulezi, as the responsible minister, and of Mandela's estranged wife Winnie Mandela as deputy. "Their lack of experience in arts, culture, science or technology is one of the few things they have in common," commented the Cape Times.

Ngubane is a mild-mannered 52-yearold physician and ardent Zulu nationalist. He was Minister of Health in the former selfgoverning territory of Kwazulu, and chief negotiator for Buthelezi's Inkatha party in the constitutional negotiations. His appointment reflects the provisions of the interim constitution, which required Inkatha be given three cabinet positions, as it received a surprisingly large 10 per cent of the national vote in the elections.

Winnie Mandela, 59, was formerly a social worker, and headed the welfare department of the African National Congress (ANC) before resigning two years ago following her separation from her husband. She herself has been reported in the media as describing her appointment as "weird".

One thing is certain. With her flair for controversy - and unless responsibility is

\section{Russia is urged to lift science spending}

\footnotetext{
Moscow. Boris Saltykov, the Russian science minister, has proposed that the government commit itself to spending a minimum of four per cent of the state budget on research. Although considerably less than the level of funding enjoyed in the mid$1980 \mathrm{~s}$, it is still higher than the 3 per cent of the budget which science received last year.

The proposal was made as part of a draft law on science and technology policy presented to the government Presidium earlier this month. Among its supporters was Yuri Yarov, the deputy prime minister, who said it was "vital" to fix a minimum level of support for science, as a further reduction in spending would have major consequences.

The Ministry of Finance, however, is reported to have opposed writing any specific targets into the new law, which is planned to specify the roles of Russia's main science funding agencies. A revised version is due to be re-submitted to the Presidium next month.
}

specifically allocated to Ngubane - science and technology will not be out of the political limelight. "We've always said that what science and technology needs is a powerful advocate in government," quipped an official.

The cabinet appointments suggest that the new ministry was seen by the ANC as one over which it could afford to relinquish control.

\section{IMAGE UNAVAILABLE FOR COPYRIGHT REASONS}$$
\text { The }
$$
world has seen two surprise appointments in the new government. The new Minister of Education is Sibusiso Bengu, rector of the University of Fort Hare. Located in

Winnie Mandela: high profile. the Eastern Cape town of Alice, it is

the alma mater of both Nelson Mandela and Buthulezi.

The 60-year-old Bengu has a doctorate in international relations from the University of Geneva, and wide experience at different levels of education, having worked both as a school-teacher and a trainingcollege lecturer in Natal, and as a professor at the University of Zululand. For 12 years he was secretary for research and social action at the World Lutheran Federation in Switzerland.

Bengu says that his first priority is to establish a single system of education for the country. Mandela is due to announce shortly that all 18 existing education departments will fall under the new ministry, which will then be responsible for integrating personnel from the existing departments into one national and nine provincial departments.

Bengu says that he expects to appoint a new director-general within a week. One of the most likely candidates, however, Jakes Gerwel, rector of the University of the Western Cape, has already been snapped up by Mandela to fill this post in his own office.

The new minister of health is Nkosazana Dlamini, 45, a researcher with the Medical Research Council (MRC). An exile who qualified as a physician at the University of Bristol in the United Kingdom, Dlamini returned to join the MRC's Durban centre in 1991, where she has been working on AIDS and maternal and child health.

South Africa's re-admittance to the World Health Organization earlier this month should ensure the support of the international community in implementing new programmes. More importantly, it signals an end to isolation from international scientific bodies.

Michael Cherry

\section{Scientists join the funding queue}

Cape Town. The most important task facing South Africa's new Ministry of Arts, Culture, Science and Technology, according to many of the country's scientists, is to persuade the government to increase the research budget in the face of its many other spending priorities.

Preliminary allocations for this year's budget total R787 million (US $\$ 222$ million), only 4 per cent higher than last year at a time when inflation is running at 9 per cent. Furthermore, although the budget was approved by the Transitional Executive Council in March, it could still be amended before it is tabled in parliament next month.

The most significant feature of this year's budget is that additional funds have been allocated to the government's major funding agency, the Foundation for Research Development. This is the body that supports research at universities, 'technikons' and museums, and runs three national research facilities. It is proposed to increase its budget by 23 per cent to R143 million, R16 million of this being earmarked for replacing obsolete equipment.

The proposed allocation to the Medical Research Council has increased by 3.5 per cent to R48 million, and that to the Human Sciences Research Council by 6 per cent to
R81 million. Both agencies spend a relatively large proportion of their funds on university research groups and other external laboratories.

In contrast, allocations to the three councils with little or no agency functions will decrease as a proportion of the total budget, although continuing to make up by far the greatest portion of it.

Funding for the Council for Scientific and Industrial Research, which conducts inhouse applied research, will grow by only one per cent, to R233 million. The budget of the Agricultural Research Council has decreased by 0.5 per cent to R220 million, and that of the Minerals Technology Council by 5 per cent, to R61 million.

This is the last research budget to be allocated on the present system, under which a cabinet committee made up of the ministers of education, health, trade and industry, and mineral and energy affairs divides up the budget after taking secret advice from the Scientific Advisory Council.

The entire research budget is likely to become the responsibility of the new council from next year. One of Ngubane's first tasks will be to appoint a new advisory council, as the term of office of the present council expires at the end of June. M. C. 